\title{
A UTILIZAÇÃO DESCRITERIOSA DA DESCONSIDERAÇÃO DA PERSONALIDADE JURÍDICA COMO FATOR DE ELEVAÇÃO DE RISCO PARA O EXERCÍCIO DA ATIVIDADE EMPRESARIAL*
}

\author{
Selma Groehs Martins*** \\ André Vátimo Argiles****
}

\section{RESUMO}

A personalidade jurídica é um instituto criado para facilitar e incentivar as atividades dos empresários, criando uma efetiva separação entre o patrimônio pessoal dos sócios e da pessoa jurídica. A redução do risco do empreendimento é a sua principal função de incentivo. Como toda construção jurídica, a personalidade jurídica também pode ser utilizada para fins de fraude. Para lidar com este tipo de situação surge a desconsideração da personalidade jurídica, medida criada para ser excepcional e para ser aplicada somente em casos de fraude e abuso. 0 que se verifica é uma interpretação diversificada do tema quando se busca diferentes ramos do direito brasileiro, tratados neste artigo mais especificamente a diferença de tratamento da desconsideração da personalidade jurídica entre as áreas cível e trabalhista. Evidenciando assim um grande fator de elevação do risco da atividade empresarial.

Palavras-chave: Desconsideração da Personalidade Jurídica. Atividade empresarial. Responsabilidade Limitada. Risco.

* Artigo apresentado ao Curso de Bacharelado em Direito do Centro Universitário Metodista - IPA, como requisito parcial para obtenção do Grau de Bacharel em Direito.

** Graduandado Curso de Bacharelado em Direito do Centro Universitário Metodista - IPA.

*** Orientador do artigo, Mestre em Direito e Professor do Curso de Bacharelado em Direito do Centro Universitário Metodista - IPA. 


\section{THE DESCRIPTIVE UTILIZATION OF THE DISREGARD DOCTRINE AS A FACTOR FOR RISK ENHANCEMENT FOR THE EXERCISE OF BUSINESS ACTIVITY}

\section{ABSTRACT}

The legal personality is an institution created to facilitate and encourage the activities of entrepreneurs, creating an effective separation between the personal patrimony of the company's partner and the legal person. Risk reduction of the enterprise is its main incentive function. Like any legal construct, legal personality can also be used for fraudulent purposes. To deal with this type of situation, there arises the disregard doctrine a measure created to be exceptional and to be applied only in cases of fraud and abuse. What is observed is a diverse interpretation of the theme when looking at different branches of Brazilian law. Discussed in this article more specifically is the difference in treatment of disregard doctrine between the civil and labor areas. This indicates a significant factor in raising the risk of business activity.

Key words: Disregard Doctrine. Business activity. LimitedLiability. Risk.

\section{INTRODUÇÃO}

A principal característica da criação de uma pessoa jurídica é a sua autonomia patrimonial que tem por objetivo principal a separação de uma parcela do capital da pessoa física para a efetivação da atividade, e partir de então, a pessoa jurídica passa a responder por suas obrigações com o seu próprio capital.

Todos os tipos societários existentes no ordenamento jurídico brasileiro possuem algum tipo de proteção ao seu capital, seja com a ordem de preferência dando prioridade aos bens utilizados para a atividade ou nos mais usados atualmente que são os que limitam a responsabilidade do sócio ao capital investido. Estes últimos serão os mais abordados neste artigo, por serem os alvos da desconsideração da personalidade jurídica.

0 instituto da desconsideração da personalidade jurídica encontra-se amplamente positivado em nosso ordenamento jurídico. Como principais dispositivos se destacam: o Código Civil 
(artigo50), Código Processo Civil (artigo 133 e seguintes), Código de Defesa do Consumidor (artigo 28) servindo como mecanismo de controle para que os empresários não se utilizem da criação da personalidade jurídica para o cometimento de fraude e abuso.

Ocorre que a aplicação deste instituto deve ser muito bem analisada, pois não se trata apenas de uma ferramenta jurídica, ele tem um grande efeito na economia. Se for mal aplicado e generalizado pode elevar o risco de se empreender, afastando assim as possibilidades de maiores investimentos.

Para visualizar como o instituto vem sendo aplicado será realizada a análise das decisões do último ano do Tribunal de Justiçado Estado do Rio Grande do Sul e do Tribunal Regional do Trabalho da 4⿳a Região acerca do assunto.

Isso leva ao tema delimitado da presente pesquisa: a utilização não criteriosa da desconsideração da personalidade jurídica como fator de elevação de risco para o exercício da atividade empresarial.

Para o enfrentamento do tema acima, destacam-se os seguintes problemas de pesquisa: de que forma a desconsideração da personalidade jurídica vem sendo aplicada pelo Tribunal de Justiça do Estado do Rio Grande do Sul e pelo Tribunal Regional do Trabalho da 4a ${ }^{a}$ Região? Da forma como vem sendo aplicada a desconsideração, é possível afirmar que contribui para ampliação do risco do exercício de atividades empresariais e, consequentemente, traz impactos negativos para a economia do país? A análise dos julgados dos tribunais gaúchos poderá resultar em duas hipóteses: a primeira sendo a aplicação de forma adequada perante a legislação, regulando somente os casos em que houve abuso ou fraude, e assim protegendo a economia dos empresários que desvirtuam a finalidade das pessoas jurídicas, e a segunda sendo a aplicação desmedida, gerando o aumento do risco da atividade empresarial.

O objetivo geral da pesquisa é analisar como o uso não criterioso do instituto da desconsideração da personalidade jurídica 
pelos tribunais pátrios, principalmente pela Justiça do Trabalho, traz impactos negativos para a economia do país, visto que amplia o risco do exercício de atividades econômicas e compromete a existência da própria pessoa jurídica. Os objetivos específicos são: realizar pesquisa doutrinária sobre a autonomia da pessoa jurídica aliada à limitação de responsabilidade como fator de redução de risco no exercício da atividade empresarial, realizar pesquisa doutrinária sobre o instituto da desconsideração da personalidade jurídica, pesquisar as decisões do último ano do Tribunal de Justiça do Estado do Rio Grande do Sul e do Tribunal Regional do Trabalho da 4⿳a Região acerca do assunto e pesquisar qual o impacto que o uso adequado ou o desmedido teriam na aferição do risco no exercício da atividade empresária.

Este tema se revela importante para identificar como a aplicação de institutos jurídicos, aqui especificamente a desconsideração da personalidade jurídica, interferem diretamente nas outras áreas da sociedade, buscando, pelo menos, um entrelaçamento maior entre o direito e a economia. É importante que ao aplicar os institutos jurídicos, os tribunais levem em conta este impacto. Ao abrir a possibilidade de desconsideração da personalidade jurídica em muitos casos, estes tribunais estariam interferindo drasticamente no risco que os empresários consideram quando tomam a decisão de investir ou não. Portanto se o uso desta ferramenta for desmedido poderia estar interferindo na economia. 0 tema tem relevância teórica e prática o que por si só justifica a escolha do mesmo.

\section{AUTONOMIA PATRIMONIAL DA PESSOA JURÍDICA ALIADA À LIMITAÇÃO DE RESPONSABILIDADE COMO FATOR DE REDUÇÃ̃O DE RISCO NO EXERCÍCIO DA ATIVIDADE EMPRESARIAL}

Para o estudo da desconsideração da personalidade jurídica é necessário que se tenha o entendimento do significado do termo sociedade que é o acordo de vontades entre duas ou mais pessoas para a consecução de atividade empresária que busca resultado financeiro. 
Este acordo de vontades desde a entrada em vigor do Código Civil de 1916 resultou na criação de um novo sujeito de direito, a pessoa jurídica, que passou a ser considerada apta a contrair direitos e obrigações próprias que não se confundem com a capacidade de seus sócios. Nessa medida, Borba escreve que:

Além de direitos, obrigações e patrimônio, conta ainda a sociedade com uma nacionalidade (brasileira, argentina, francesa), um domicílio (Rua da Alfândega, 18 Rio de Janeiro, por exemplo), um nome (Siqueiros\& Cia., por exemplo), envolvendo-se até mesmo em relações de família, uma vez que pode dispor de sociedades mães (holdings) e sociedades filhas (subsidiárias). Nascem com a constituição e morrem com a liquidação. ${ }^{1}$

Este sujeito de direito hoje é um elemento de limitação do risco econômico inerente a empresa, pois existe a possibilidade de restrição do risco patrimonial de cada um dos sócios pela responsabilidade limitada, onde sua extensão se dará a partir da escolha do tipo societário.

A limitação de responsabilidade é considerada o elemento econômico mais evidente na determinação do risco assumido pelos sócios, quando decidem investir capital na celebração de um contrato de sociedade que seja personificada, gerando assim a pessoa jurídica. Conforme Camargo, a principal vantagem na constituição de uma pessoa jurídica é a "limitação da responsabilidade dos seus membros por dívidas atribuídas à pessoa jurídica, naquelas modalidades associativas em que há tal prerrogativa legal."2

1 BORBA, José Edwaldo Tavares. Direito societário. 16. ed. São Paulo: Atlas, 2018, p. 42.

2 CAMARG0, André Antunes Soares de. A pessoa jurídica: um fenômeno social antigo, recorrente, multidisciplinar e global. In: FRANÇA, Erasmo. (Org.). Direito societário contemporâneo.São Paulo: QuartierLatin, 2009, p. 283-284. 
As vantagens na criação de uma pessoa jurídica incentivada pelo ordenamento jurídico também interessam ao Estado, que permite a sua criação e consagra regras de limitação de responsabilidade dos sócios para o fim maior que é o de estimular o exercício da atividade econômica consagrado na Constituição Federal. ${ }^{3}$

Quando da criação de uma pessoa jurídica, esta passa a ter suas próprias características, uma vez que é completamente autônoma em relação a figura de seus sócios e administradores. Sendo a mais importante delas, a autonomia patrimonial. É importante referir que:

0 conceito de pessoa jurídica foi constituído à imagem e semelhança do conceito de pessoa física. Ambas são sujeitos de direitos e obrigações, atuando na ordem jurídica. Os sócios, ao constituírem a sociedade, transferem-lhe bens que passam a compor o patrimônio social. [...] Com o exercício de sua atividade, a sociedade realizará negócios nos quais auferirá lucros ou sofrerá prejuízos, com a consequente ampliação ou redução do próprio patrimônio. Esse patrimônio não se confunde com o dos sócios. Nenhuma dívida da sociedade poderá ser cobrada do sócio ou vice-versa. ${ }^{4}$

Ao retratar as características das pessoas jurídicas, Fábio Ulhoa Coelho destaca a titularidade negocial, a titularidade processual e a responsabilidade patrimonial. Nesta última evidencia que o patrimônio da sociedade é inconfundível e incomunicável com o patrimônio individual de cada um de seus sócios. Assim, sujeito de direito personalizado autônomo, a pessoa jurídica responderá com seu patrimônio pelas obrigações que assumir. ${ }^{5}$ Tra-

3 RAMOS, André Luiz Santa Cruz. Direito empresarial. 7. ed. São Paulo: Método, 2017, p. 460.

4 BORBA, op. cit., p. 42.

5 COELHO, Fábio Ulhoa. Manual de direito comercial: direito de empresa. 23. ed. São Paulo: Saraiva, 2011, p. 140. 
ta-se de uma responsabilidade ilimitada, a mesma que se atribui a pessoa física. Ou seja, cada pessoa responde pelas obrigações que contrair com a totalidade do seu patrimônio. Afinal, a garantia dos credores é o patrimônio do devedor, conforme estabelece o Código de Processo Civil em seu artigo 789: "o devedor responde com todos os seus bens presentes e futuros para o cumprimento de suas obrigações, salvo as restrições estabelecidas em lei."

Ao pensar nas consequências desta autonomia, precisa-se fazer uma análise interdisciplinar do direito, buscando analisar o direito a partir de instrumentos de outras ciências como a economia. Essa análise do direto a partir dos institutos da economia gerou uma corrente teórica chamada análise econômica do direito, que assim está definida:

A análise econômica do direito importa no estudo interdisciplinar de temas, considerando as particularidades de cada disciplina em proveito de um entendimento comum. A ideia básica é usar ferramentas da economia para permitir que o advogado, conhecendo os institutos da economia, possa trabalhar o estudo e aplicação do direito de forma prática, abandonando a noção hermenêutica do direito como ferramenta de distribuição de justiça. ${ }^{6}$

Utilizando-se dos conceitos da análise econômica do direito, a finalidade da pessoa jurídica vai além do estabelecido na legislação, conforme entendimento:

A pessoa jurídica no direito empresarial é, hoje, antes de mais nada, um elemento de limitação do risco econômico inerente à empresa. Em uma sociedade empresária a personificação decorrente do contrato é não uma finalidade abstrata, mas ato

6 CATEB, Alexandre Bueno; PIMENTA, Eduardo Goulart. Análise econômica do direito societário. In: TIMM, Luciano. (Org.). Direito e economia no Brasil. 2. ed. São Paulo: Atlas, 2014, p. 225. 
com a função econômica concreta de proporcionar aos participantes do empreendimento comum a possibilidade de anteverem, planejarem e, principalmente, restringirem o risco patrimonial de cada um deles pela responsabilidade limitada do sócio. ${ }^{7}$

A influência da autonomia patrimonial da pessoa jurídica se dá, principalmente, na significativa redução de riscos ao sócio, que tem garantido seu direito de destacar parte de seu patrimônio pessoal para integrar o patrimônio da sociedade, e ao fazer isto ainda se resguarda de eventuais prejuízos ao primeiro. ${ }^{8}$ Isto fica mais evidente nos tipos de sociedade em que se agrega a limitação de responsabilidade para os sócios, como o que ocorre na sociedade limitada e na sociedade por ações.

A regra para a sociedade limitada está disposta no artigo 1.052 do Código Civil, que estabelece que a responsabilidade de cada sócio é restrita ao valor de suas quotas. Portanto, neste tipo de sociedade o sócio tem sua responsabilidade limitada ao valor integralizado ao capital social.

A responsabilidade limitada das sociedades por ações está descrita na Lei 6.404/76: "Art. 1ํ: A companhia ou sociedade anônima terá o capital dividido em ações, e a responsabilidade dos sócios ou acionistas será limitada ao preço de emissão das ações subscritas ou adquiridas." ${ }^{\prime 9}$ Assim, fica clara a intenção do legislador em limitar a responsabilidade dos sócios nos casos de dívidas das sociedades.

Mesmo nos casos de sociedades constituídas sob formas que não limitam a responsabilidade dos sócios perante as dívidas da empresa, o patrimônio pessoal do sócio tem a proteção do princípio da subsidiariedade, que condiciona a afetação deste

\footnotetext{
Ibid, p. 227-228.

8 RAMOS, op. cit., p. 310.

9 BRASIL. Lei no 6.404, de 15 de dezembro de 1976. Diário Oficial da União, Brasília, 1976, paginação irregular.
} 
somente após o esgotamento de todo o patrimônio social, conforme estabelece o regramento das sociedades simples no art. 1024 do Código Civil: "Art. 1.024: Os bens particulares dos sócios não podem ser executados por dívidas da sociedade, senão depois de executados os bens sociais."10

Analisando este cenário, economicamente, se reduz muito os riscos da atividade empreendedora, o que se torna um significativo incentivo. Sobre esta redução de riscos, Tomazette afirma que:

A existência desta autonomia é que torna a sociedade um dos mais importantes instrumentos do desenvolvimento da moderna economia de mercado, na medida em que se permite a redução dos riscos no exercício da atividade empresarial, assegurando o destaque de determinada parcela patrimonial para o exercício da atividade. ${ }^{11}$

Esta ideia também é reforçada por André Luiz Santa Cruz Ramos, para quem:

O princípio da autonomia patrimonial das pessoas jurídicas, consagrado no art. 1.024 do Código Civil, constitui uma importantíssima ferramenta jurídica de incentivo ao empreendedorismo, na medida em que consagra a limitação de responsabilidade - a depender do tipo societário adotado - e, consequentemente, atua como importante redutor do risco empresarial. ${ }^{12}$

A reflexão sobre esta redução de riscos que a autonomia patrimonial, aliada à limitação de responsabilidade dos sócios estabelece, nos leva a uma importante consequência: a redução,

10 BRASIL. Lei no 10.406 , de 10 de janeiro de 2002. Diário Oficial da União, Brasília, 2002, paginação irregular.

11 TOMAZETTE, Marlon. Curso de direito empresarial: teoria geral e direito societário. 6. ed. São Paulo: Atlas, 2014, p. 236. V. 1.

12 RAMOS, op. cit., p. 460. 
na prática, dos tipos societários adotados no momento da constituição dos negócios.

Hoje, há previsão no ordenamento jurídico de inúmeros tipos societários, mas o que se verifica é a preferência pelos que garantem a limitação de responsabilidade, como a sociedade limitada (LTDA), ${ }^{13}$ a empresa individual de responsabilidade limitada (EIRELI) ${ }^{14}$ e a sociedade anônima (S.A.), ${ }^{15}$ estando em completo desuso aquelas sociedades em que todos ou parte dos sócios responde de forma ilimitada pelas obrigações da sociedade (sociedade em nome coletivo, ${ }^{16}$ sociedade em comandita simples ${ }^{17}$ e sociedade em comandita por ações). ${ }^{18}$ Tanto assim que Paula Forgioni afirma que:

Em outros tempos, os comerciantes valiam-se de diversos tipos societários para acomodação de seus interesses. Agora, as opções resumem-se em

13 Art. 1.052, CC: Na sociedade limitada, a responsabilidade de cada sócio é restrita ao valor de suas quotas, mas todos respondem solidariamente pela integralização do capital social. In: BRASL, op. cit., 2002, paginação irregular.

14 Art. 980-A, CC: A empresa individual de responsabilidade limitada será constituída por uma única pessoa titular da totalidade do capital social, devidamente integralizado, que não será inferior a 100 (cem) vezes o maior salário-mínimo vigente no País. [...] § 6º Aplicam-se à empresa individual de responsabilidade limitada, no que couber, as regras previstas para as sociedades limitadas. Ibid.

15 Art. 1ํㅡㄴ Lei 6.404/76: A companhia ou sociedade anônima terá o capital dividido em ações, e a responsabilidade dos sócios ou acionistas será limitada ao preço de emissão das ações subscritas ou adquiridas. In: BRASIL, op. cit., 1976, paginação irregular.

16 Art. 1.039, CC: Somente pessoas físicas podem tomar parte na sociedade em nome coletivo, respondendo todos os sócios, solidária e ilimitadamente, pelas obrigações sociais. In: BRASIL, 2002, op. cit., paginação irregular.

17 Art. 1.045, CC: Na sociedade em comandita simples tomam parte sócios de duas categorias: os comanditados, pessoas físicas, responsáveis solidária e ilimitadamente pelas obrigações sociais; e os comanditários, obrigados somente pelo valor de sua quota. Ibid.

18 Art. 1.091, CC: Somente o acionista tem qualidade para administrar a sociedade e, como diretor, responde subsidiária e ilimitadamente pelas obrigações da sociedade. Ibid. 
praticamente três, que permitem a limitação total da responsabilidade dos sócios frente às obrigações sociais: sociedades anônimas, sociedades limitadas e as empresas individuais de responsabilidade limitada, criadas em 2011 pela Lei $12.441 .^{19}$

A estatística produzida pela Junta Comercial, Industrial e Serviços do Estado do Rio Grande do Sul demonstra a verdadeira ocorrência deste fenômeno a qual confirma a maciça opção pela sociedade limitada (LTDA), além da empresa individual de responsabilidade limitada (EIRELI) e da sociedade anônima (S.A.):

Tabela 1 - Empresa - Constituição

\begin{tabular}{c|c|c|c|c|c|c|c|c} 
Mês & Empresário & LTDA & S/A & $\begin{array}{c}\text { Coope- } \\
\text { rativa }\end{array}$ & MEI & EIRELI & Outros & Total \\
\hline Jan & 851 & 936 & 5 & 3 & 9.364 & 341 & 2 & 11.502 \\
\hline Fev & 707 & 794 & 1 & 5 & 8.078 & 245 & 6 & 9.836 \\
\hline Mar & 1.374 & 1.237 & 3 & 2 & 10.184 & 412 & 1 & 13.213 \\
\hline Abr & 859 & 983 & 1 & 3 & 7.973 & 346 & 0 & 10.165 \\
\hline Mai & 1.145 & 1.181 & 10 & 0 & 10.354 & 374 & 3 & 13.067 \\
\hline Jun & 1.145 & 1.304 & 8 & 3 & 213 & 448 & 1 & 3.122 \\
\hline Jul & 959 & 1.147 & 5 & 4 & 24 & 353 & 2 & 2.494 \\
\hline Ago & 1.172 & 1.454 & 11 & 8 & 171 & 557 & 2 & 3.375 \\
\hline Set & 980 & 1.159 & 8 & 2 & 165 & 411 & 0 & 2.725 \\
\hline Out & 847 & 1.044 & 7 & 2 & 0 & 387 & 4 & 2.291 \\
\hline Nov & 931 & 1.185 & 4 & 1 & 0 & 415 & 1 & 2.537 \\
\hline Dez & 961 & 1.016 & 3 & 3 & 6.763 & 374 & 2 & 9.122 \\
\hline Tot. & 11.931 & 13.440 & 66 & 36 & 53.289 & 4.663 & 24 & 83.449
\end{tabular}

Fonte: Rio Grande do Sul. ${ }^{20}$

19 FORGIONI, Paula Andrea. A evolução do direito comercial brasileiro: da mercancia ao mercado. 3. ed. São Paulo: Editora Revista dos Tribunais, 2016, p. 111.

20 RIO GRANDE DO SUL. Junta Comercial, Industrial e Serviços do Rio Grande do Sul. Relação por Ano das Estatísticas. Porto Alegre, 2017, paginação irregular. 
Os benefícios trazidos pelo instituto da limitação de responsabilidade podem ser mal utilizados, e para isto, se faz necessário que exista uma regra de exceção. Com o objetivo de coibir o mau uso da personalidade jurídica aliada a limitação de responsabilidade, foi desenvolvido o instituto da desconsideração da personalidade jurídica. Trata-se de ferramenta que permite, em casos excepcionais, a desconsideração da autonomia patrimonial para que os sócios venham a responder com seu patrimônio pessoal por obrigações que não são suas, mas da pessoa jurídica da qual participam como sócios.

\title{
3 NOÇÕES SOBRE O INSTITUTO DA DESCONSIDERA- ÇÃO DA PERSONALIDADE JURÍDICA
}

A conquista do benefício da limitação de responsabilidade dos sócios perante as dívidas da empresa abre margem para que empresários com intenções fraudulentas se utilizem deste benefício para obter vantagens. Com base nestes casos, a doutrina e a jurisprudência, inicialmente em países como Inglaterra, Estados Unidos e Alemanha, começaram a discutir sobre uma forma de conter tais propósitos fraudulentos.

0 caso apontado pela doutrina como referência, ocorreu na Inglaterra, em 1897 e é conhecido como Salomon versus Salomon \& Co. Ltd.

\begin{abstract}
No caso em referência, a sentença de $1^{\circ}$ grau entendeu pela possibilidade de desconsideração da personalidade jurídica da Salomon \& Co. Ltd., após reconhecer que Mr. Salomon tinha, na verdade, o total controle societário sobre a sociedade, não se justificando a separação patrimonial entre ele e a pessoa jurídica. Essa decisão é considerada, pois, a grande precursora da teoria da desconsideração, não obstante tenha sido posteriormente reformada pela Casa dos Lords, a qual entendeu pela impossibilidade de desconsideração, fazendo prevalecer a separação entre os patrimônios de Mr. Salomon e de sua sociedade. ${ }^{21}$
\end{abstract}

${ }^{21}$ RAMOS, op. cit., p. 460, grifo do autor. 
No Brasil, a doutrina foi trazida por juristas como Rubens Requião, que trouxe as ideias dos juristas do exterior e defendeu a aplicação da teoria da desconsideração da personalidade jurídica pela via jurisprudencial, uma vez que a legislação brasileira ainda não tratava sobre o assunto.

A forma pela qual Requião aborda a questão dispensa qualquer acréscimo. Indagar da adequação da teoria da desconsideração ao Direito brasileiro é, na verdade, indagar da atitude que deve o juiz assumir quando está diante de uma fraude, ou abuso de direito, perpetrados através da utilização do expediente da autonomia patrimonial: deve o juiz agarrar-se aos conceitos tradicionais, tomando por absoluto o direito à personalização das pessoas jurídicas, renunciando à coibição da fraude e do abuso de direito, ou , ao contrário, deve realizar a coibição ao mau uso da pessoa jurídica com o aproveitamento de uma teoria que, embora nascida no exterior e ainda não consagrada pelo legislador brasileiro, possibilita esta atitude sem comprometimento do instituto? ${ }^{22}$

Primeiramente se encontravam duas vertentes jurisprudenciais, uma que receava em coibir o mau uso da pessoa jurídica para não ir contra o princípio da autonomia patrimonial, e outra que discutia a própria criação da pessoa jurídica e não seu mau uso. $^{23}$

A teoria da desconsideração da personalidade jurídica surge na doutrina como remédio para as dúvidas que eram apontadas em situações fraudulentas, e ainda buscando preservar a empresa em si, uma vez que seu propósito é a desconsideração casuística, ou seja, apenas para o caso que está sendo discutido, não se fala

22 COELHO, Fábio Ulhoa. Desconsideração da Personalidade Jurídica. São

Paulo: Editora Revista dos Tribunais, 1989,p. 35.

${ }^{23}$ Ibid, p. 16. 
em dissolução da sociedade e sim em desconsideração da personalidade jurídica em determinada situação. ${ }^{24}$

Fábio Ulhoa Coelho define a desconsideração da personalidade jurídica como uma elaboração teórica destinada à coibição das práticas fraudulentas que se valem da pessoa jurídica, ao mesmo tempo que se tenta preservar o instituto da pessoa jurídica, uma vez que este não é o problema e sim o mau uso que se pode fazer dele. Ainda ressalta que não atinge a validade do ato constitutivo, mas apenas a sua eficácia episódica. ${ }^{25}$

Com o intuito de preservar a empresa, está sendo observada ainda, "a vertente que concebe a função social da empresa como incentivadora do exercício da atividade empresarial." ${ }^{26}$

O fato de a desconsideração não atingir a empresa como um todo é a grande vantagem deste instituto. Fábio Ulhoa Coelho ressalta que:

Por apenas suspender a eficácia do ato constitutivo, no episódio sobre o qual recai o julgamento, sem invalidá-lo, a teoria da desconsideração preserva a empresa, que não será necessariamente atingida por ato fraudulento de um de seus sócios, resguardando-se, desta forma, os demais interesses que gravitam ao seu redor, como o dos empregados, dos demais sócios, da comunidade, etc. ${ }^{27}$

Importante ressaltar que não se pode utilizar a terminologia despersonalização, uma vez que esta tem ideia completamente oposta ao que se está buscando. Despersonalizar é retirar por completo a personalidade jurídica, o que se busca aqui é a desconsideração que atua de forma casuística e momentânea. Tomazette explica que:

24 COELHO, 1989, op. cit., p. 13.

25 Ibid, p. 13.

26 CANTALI, Fernanda Borghetti; GUENO, Aline Woltz. A Desconsideração da Personalidade Jurídica para a Responsabilização Patrimonial de Ex-Sócio. Justiça \& Sociedade, Porto Alegre, v. 1, n. 1, p. 117-146, 2016, p. 123.

27 COELHO, 2011, op. cit., p. 154. 
Despersonalizar significa anular a personalidade, o que não ocorre na desconsideração. Nesta, não se anula a personalidade, ao contrário, esta resta mais protegida; não se trata de despersonalização (anulação definitiva da personalidade), mas de simples desconsideração, retirada momentânea da eficácia da personalidade. ${ }^{28}$

Atualmente, no Brasil, a regra matriz da desconsideração da personalidade jurídica está no Código Civil, que estabelece:

Art. 50: Em caso de abuso da personalidade jurídica, caracterizado pelo desvio de finalidade, ou pela confusão patrimonial, pode o juiz decidir, a requerimento da parte, ou do Ministério Público quando lhe couber intervir no processo, que os efeitos de certas e determinadas relações de obrigações sejam estendidos aos bens particulares dos administradores ou sócios da pessoa jurídica. ${ }^{29}$

Tal dispositivo é claro quando impõe condição de abuso caracterizado por desvio de finalidade ou confusão patrimonial para que se possa atingir o patrimônio pessoal dos sócios.

Para compreender o desvio de finalidade é necessário estabelecer conceito para finalidade, que é verificada através de dois parâmetros: objeto social, que consiste na atividade descrita nos atos constitutivos da sociedade para atingir o seu fim; e interesse social, este mais complexo, mas que se pode, simplificadamente, estabelecido como uma diretriz da sociedade que deve levar em conta os interesses dos sócios ou acionistas, ou ainda em sentido mais amplo, também os interesses públicos ou coletivos. ${ }^{30}$

28 TOMAZETTE, op. cit., p. 242.

29 BRASIL, 2002, op. cit., paginação irregular.

30 SILVA, Leonardo Toledo da. Abuso da desconsideração da personalidade jurídica. São Paulo: Saraiva, 2014, p. 57. 
Confusão patrimonial se dá quando os sócios não fazem distinção entre os seus patrimônios pessoais e os da sociedade, agindo como se fossem os proprietários destes e não apenas como titulares de direito a resultados. ${ }^{31}$ Esta é de fácil comprovação quando da análise dos registros contábeis da sociedade.

Em recente decisão o Superior Tribunal de Justiça assegurou tais conceitos ao decidir:

A inexistência ou não localização de bens da pessoa jurídica não é condição para a instauração do procedimento que objetiva a desconsideração, por não ser sequer requisito para aquela declaração, já que imprescindível a demonstração específica da prática objetiva de desvio de finalidade ou de confusão patrimonial. ${ }^{32}$

É certo que o objetivo da criação da desconsideração da personalidade jurídica se deu para evitar unicamente casos de fraude e desvio de função da pessoa jurídica, porém sugiram outras teorias sobre a aplicação deste instituto, entre elas a de que este poderia ser aplicado de forma mais ampla.

Na aplicação mais ampla, também chamada de teoria menor,é defendido que o mero inadimplemento da empresa pode dar causa a sua desconsideração. No direito brasileiro esta teoria parte inicialmente da interpretação dada para a regra contida no parágrafo 5ํㅜ do artigo 28 do Código de Defesa do Consumidor:

Art. 28. 0 juiz poderá desconsiderar a personalidade jurídica da sociedade quando, em detrimento do consumidor, houver abuso de direito, excesso de poder, infração da lei, fato ou ato ilícito ou violação dos estatutos ou contrato social. A descon-

31 Ibid, p. 58-59.

32 TRIBUNAL DE JUSTIÇA DO PARANÁ. 4a Turma. Resp 1.729.554/SP. Relator: Ministro Luis Felipe Salomão, julgado em 08/05/2018. Diário da Justiça Eletrônico, Curitiba, 2018, p. 74. 
sideração também será efetivada quando houver falência, estado de insolvência, encerramento ou inatividade da pessoa jurídica provocados por má administração.

[...]

$\S 5^{\circ}$ Também poderá ser desconsiderada a pessoa jurídica sempre que sua personalidade for, de alguma forma, obstáculo ao ressarcimento de prejuízos causados aos consumidores. ${ }^{33}$

No direito do consumidor, o que se utiliza como justificativa para esta aplicação é de que existe desigualdade na relação, sendo o consumidor sempre a parte mais frágil da mesma.

Após esta regra, outras no mesmo sentido foram criadas, como por exemplo na Lei de Crimes Ambientais ${ }^{34}$ e na Lei Antitruste. ${ }^{35}$

Contudo, o ramo do direito que mais se utiliza dessa forma alargada de aplicação da desconsideração da personalidade jurídica, não se exigindo a fraude ou o abuso de direito, mas sim o mero inadimplemento da pessoa jurídica é o Direito do Trabalho. Para justificar a utilização da desconsideração no mero inadimplemento a doutrina e jurisprudência trabalhista esclarece que os interesses dos trabalhadores são maiores do que o princípio da autonomia patrimonial.

33 BRASIL. Lei no 8.078, de 11 de setembro de 1990. Diário Oficial da União, Brasília, 1990, paginação irregular.

34 Art. 4ํㅡ, Lei 9.606/98: Poderá ser desconsiderada a pessoa jurídica sempre que sua personalidade for obstáculo ao ressarcimento de prejuízos causados à qualidade do meio ambiente. In: BRASIL. Lei no 9.606, de 16 de fevereiro de 1998. Diário Oficial da União, Brasília, 1988, paginação irregular.

35 Art. 34, Lei 12.529/11: A personalidade jurídica do responsável por infração da ordem econômica poderá ser desconsiderada quando houver da parte deste abuso de direito, excesso de poder, infração da lei, fato ou ato ilícito ou violação dos estatutos ou contrato social. In: BRASIL. Lei no 12.529 , de 30 de novembro de 2011.Diário Oficial da União, Brasília, 2011, paginação irregular. 
Ari Pedro Lorenzetti, escreve que existe a necessidade de estabelecer os limites até onde a sociedade pode conviver com os inconvenientes acarretados pela personificação. ${ }^{36}$

Ainda, estabelecido como princípio informador do Direito do Trabalho que o empregado não corre o risco do empreendimento, já que também não participa dos lucros, não havendo bens na sociedade que suportem a execução, os sócios deverão responder pelos débitos trabalhistas da empresa com seus patrimônios particulares. ${ }^{37}$

Tais argumentos fundamentam decisões como:

EMENTA AGRAVO DE PETIÇÃO. DESCONSIDERAÇÃO DA PERSONALIDADE JURÍDICA. Conforme a teoria objetiva da desconsideração da personalidade jurídica, prevista no artigo 28 do CDC e artigo $4^{\circ}$ o da Lei no 9.605/1998, basta o credor demonstrar a insolvência da parte contrária que será possível retirar o véu da pessoa jurídica, com o consequente ataque ao patrimônio dos sócios. Tal teoria objetiva, em razão da hipossuficiência do trabalhador, da natureza alimentícia dos créditos trabalhistas e de todo o sistema principiológico protecionista que foi edificado para proteger o trabalhador, é a que melhor atende aos primados do Direito do Trabalho, devendo ser utilizada enquanto não houver previsão específica nos diplomas trabalhistas. Agravo de petição interposto pelo executado Vilson Antônio Todero a que se nega provimento, no item. ${ }^{38}$

36 LORENZETTI, Ari Pedro. A Responsabilidade dos Sócios e Dirigentes no Processo do Trabalho e o Incidente de Desconsideração. In. CLAUS,Ben-hur Silveira; ALVARENGA, Rúbia Zanotellide.(Orgs.).Execução Trabalhista: o desafio da efetividade. São Paulo: LTr, 2015, p. 91.

37 OLIVEIRA, Francisco Antonio de. Comentários à Execução do Novo Código de Processo Civil: enfoques civilistas e trabalhistas. São Paulo: LTr, 2016, p. 9.

38 TRIBUNAL RERGIONAL DO TRABALHO da 4⿳亠丷厂 Região.Seção Especializada em Execução. AP 0020067-11.2014.5.04.0405. Desembargador Joao Alfredo Borges Antunes de Miranda. Diário Eletrônico, Caxias do Sul, 2018, p. 1769. 
Sobre o entendimento majoritário do direito do trabalho:

Atualmente, a moderna doutrina e a jurisprudência trabalhista encamparam a chamada teoria objetiva da desconsideração da personalidade jurídica que disciplina a possibilidade de execução dos bens do sócio, independente de os atos destes terem violado ou não o contrato, ou de haver abuso de poder. Basta a pessoa jurídica não possuir bens para ter início a execução aos bens do sócio.

No processo de trabalho, o presente entendimento se justifica em razão da hipossuficiência do trabalhador, da dificuldade que apresenta o reclamante em demonstrar a má-fé do administrador e do caráter alimentar do crédito trabalhista. ${ }^{39}$

É notável que o Direito do Trabalho se utiliza de normas que tendem a ignorar a essência de exceção da desconsideração da personalidade jurídica, como a já citada consumerista. Essa busca por justificativas para esta prática tão comum e criticável se dá por não haver uma legislação específica que a regule. Aqui é que podemos notar uma grave sensaçãode insegurança jurídica do empresário, como pode ser possível a aplicação de um instituto tão importante com os mais diversos argumentos possíveis e sem uma regra positivada?

Neste sentido, Ronaldo Zanata Pazim escreve:

Qualquer que seja a opção do julgador trabalhista ela provém muito mais de uma construção jurisprudencial do que de um comando legal, enquanto, por outro lado, a proteção do patrimônio do empresário é absoluta e expressamente prevista na lei, incólume de dúvidas.

Importa reconhecer, portanto, que, se decretada a desconsideração pela simples inadimplência ou

39 SCHIAVI, Mauro. Manual de direito processual do trabalho. 7. ed. São Paulo: LTr, 2014, p. 1001. 
pela só insuficiência patrimonial da pessoa jurídica, sem real subsunção do caso concreto a uma das hipóteses que a autorizam, a decisão representará um golpe letal ao direito empresarial, fulminando a legalidade do que ele pretendia agasalhar. ${ }^{40}$

Aqui a crítica se dá pela afronta aos critérios hoje estabelecidos pela lei, e não pelos motivos elencados pelos magistrados e estudiosos do direito do trabalho que estabelecem que o crédito alimentar está acima de qualquer outro. A ideia a ser defendida é de que para haver a devida segurança jurídica que visa estimular as pessoas a empreenderem, as regras devem ser claras e devidamente seguidas por todos os ramos do direito.

Tanto os critérios utilizados no direito do consumidor quanto os utilizados no direito do trabalho, são duramente criticados, uma vez que geram insegurança jurídica além de desvirtuar o conceito originário do instituto da desconsideração da personalidade jurídica.

Tem-se relativizado progressivamente a autoridade do princípio da autonomia patrimonial, pois para uma parcela da sociedade este não é visto com bons olhos, por parecer que se está acobertando a fraude em detrimento do credor honesto. Isto acaba por gerar a crise que atualmente passa o princípio da autonomia patrimonial e as regras de limitação de responsabilidade. ${ }^{41}$ Ainda neste sentido, Borba identifica que:

A partir do CDC, e com as demais leis que a ele se alinharam, vários magistrados, especialmente os juízes trabalhistas, passaram a aplicar essas disposições de forma indiscriminada e abrangente, em todas as áreas, como se não mais vigorasse entre

40 PAZIM, Ronaldo Zanata. A desconsideração da personalidade jurídica como um golpe letal ao direito empresarial. Revista Síntese, Direito Empresarial,São Paulo, v. 9, n. 51, Jul/Ago. 2016, p. 45.

41 RAMOS, op. cit., p. 465. 
nós a teoria da personalidade jurídica. ${ }^{42}$

A desconsideração da personalidade jurídica também pode ser aplicada da forma chamada inversa, quando se atinge os bens da empresa por dívidas pessoais dos sócios. Tal aplicação é mais comum em questões relativas ao direito de família, onde se percebe que uma das partes está ocultando patrimônio transferindo parte dele para uma pessoa jurídica, com a finalidade de fraudar partilha ou pagamento de alimentos, por exemplo. ${ }^{43}$

Uma grande inovação no sentido da aplicação da desconsideração inversa se deu com o Código de Processo Civil de 2015, que estipulou a forma como deve ser tratada em matéria processual:

Art. 133. 0 incidente de desconsideração da personalidade jurídica será instaurado a pedido da parte ou do Ministério Público, quando lhe couber intervir no processo.

[...]

$\S 2^{\circ}$ Aplica-se o disposto neste Capítulo à hipótese de desconsideração inversa da personalidade jurídica. ${ }^{44}$

Com a intenção de demonstrar na prática a utilização por vezes desmedida deste instituto, no item 4 será realizada pesquisa jurisprudencial junto ao Tribunal de Justiça do Estado do Rio Grande do Sul e ao Tribunal Regional do Trabalho da 4⿳⺈

\subsection{A Desconsideração da Personalidade Jurídica no Código} de Processo Civil

O Código de Processo Civil de 2015 trouxe uma positiva inovação no que se refere a desconsideração da personalidade

42 BORBA, op. cit., p. 42.

43 RAMOS, op. cit., p. 469.

44 BRASIL. Lei no 13.105, de 16 de março de 2015. Diário Oficial da União, Brasília, 2015, paginação irregular. 
jurídica, buscou solução para os debates jurisprudenciais sobre como o instituto deve ser tratado processualmente, trazendo o chamado incidente de desconsideração da personalidade jurídica. Importante para promover segurança jurídica para as partes do processo. Neste sentido:

Apesar de a desconsideração da personalidade jurídica estar presente nos debates jurídicos há muito tempo e ser amplamente aplicada pelos tribunais, não havia até então regulamentação do procedimento a ser utilizado para a sua aplicação. Aliás, a lacuna procedimental era apontada como um problema, já que gerava demasiada insegurança jurídica. ${ }^{45}$

0 incidente, que está previsto nos artigos 133 a 137 do Código de Processo $\mathrm{Civil}^{46}$, se inicia com o requerimento da parte ou

45 CANTALI, Fernanda Borghetti; GUENO, Aline Woltz. Dos sujeitos do processo. In: MELLO, Rafael Corte (Org.); GIORGI JR., Romulo Ponticelli (Org.). Novo código de processo civil anotado. Charleston: CreateSpaceIndependentPublishing Platform, 2015, p. 82.

${ }^{46}$ Art. 133. 0 incidente de desconsideração da personalidade jurídica será instaurado a pedido da parte ou do Ministério Público, quando lhe couber intervir no processo.

$\S 1^{\text {o }} 0$ pedido de desconsideração da personalidade jurídica observará os pressupostos previstos em lei.

$\S 2^{\circ}$ Aplica-se o disposto neste Capítulo à hipótese de desconsideração inversa da personalidade jurídica.

Art. 134. 0 incidente de desconsideração é cabível em todas as fases do processo de conhecimento, no cumprimento de sentença e na execução fundada em título executivo extrajudicial.

$\S 1^{\mathrm{o}} \mathrm{A}$ instauração do incidente será imediatamente comunicada ao distribuidor para as anotações devidas.

§ 2ํㅡㄹ Dispensa-se a instauração do incidente se a desconsideração da personalidade jurídica for requerida na petição inicial, hipótese em que será citado o sócio ou a pessoa jurídica.

$\S 3^{\circ}$ A instauração do incidente suspenderá o processo, salvo na hipótese do $\S 2$.

$\S 4^{\circ} 0$ requerimento deve demonstrar o preenchimento dos pressupostos legais específicos para desconsideração da personalidade jurídica. 
do Ministério Público, quando lhe couber intervir. Assim, pode-se concluir que o texto da lei exclui a possibilidade de instauração de ofício pelo juiz, ou seja, o incidente deve ser provocado.

Com a contribuição do artigo 134, não restam dúvidas de que o incidente poderá ser instaurado a qualquer momento do processo, inclusive no cumprimento de sentença e nas execuções fundadas em título extrajudicial.

A instauração do incidente é obrigatória e a única hipótese excetuada se dá quando a desconsideração da personalidade jurídica é alegada em petição inicial, de acordo com os princípios da celeridade e economia processual.

0 requerimento para se instaurar o incidente deve demonstrar os requisitos específicos que levam à desconsideração, remetendo aos limites impostos pela legislação, principalmente o artigo 50 do Código Civil. Importante ressaltar que o requerimento não precisará trazer todas as provas, mas sim apresentarfortes indícios para ser instaurado o incidente, uma vez que haverá o momento específico para a produção de provas. Neste sentido Neves entende que "o requerente não deve demonstrar, mas apenas alegar o preenchimento dos requisitos legais para a desconsideração, tendo o direito a produção de prova para convencer o juízo de sua alegação." ${ }^{47}$ Ainda neste sentido:

Entendemos que a norma não deve ser interpretada no sentido de que compete ao credor comprovar cabalmente o preenchimento dos pressupostos/

Art. 135. Instaurado o incidente, o sócio ou a pessoa jurídica será citado para manifestar-se e requerer as provas cabíveis no prazo de 15 (quinze) dias.

Art. 136. Concluída a instrução, se necessária, o incidente será resolvido por decisão interlocutória.

Parágrafo único. Se a decisão for proferida pelo relator, cabe agravo interno. Art. 137. Acolhido o pedido de desconsideração, a alienação ou a oneração de bens, havida em fraude de execução, será ineficaz em relação ao requerente. In: BRASIL, 2015, op. cit., paginação irregular.

47 NEVES, Daniel Amorim Assumpção. Novo Código de Processo Civil: leis 13.105/2015 e 13.256/2016. 3. ed. São Paulo: Método, 2016, p. 146. 


\begin{abstract}
motivos legais, sob pena de se inviabilizar a desconsideração. A exegese do dispositivo ressalta apenas a necessidade de apontar a insuficiência patrimonial da pessoa jurídica (ex.: insucesso na localização de bens da pessoa jurídica) e, quando exigível (teoria maior), o motivo que justifica a desconsideração (ex.: abuso de direito, fraude etc.). Cabe ao autor apontar os fatos de que tem conhecimento e ao juiz apurá-los. ${ }^{48}$
\end{abstract}

No artigo 135 ficou devidamente regulamentado o direito ao contraditório, dando oportunidade para a parte requerida se defender e expor os motivos pelos quais entende que não deve ser realizada a desconsideração. Cantali e Gueno entendem que "esta regra demonstra a devida importância que o novo Código deu as garantias processuais fundamentais consagradas pela Constituição Federal de 1988, já que assegura o contraditório e a ampla defesa." ${ }^{49}$

Quando instaurado no curso do processo, o incidente será resolvido pelo juiz por meio de decisão interlocutória, que será recorrível por agravo de instrumento. Porém, quando suscitado na petição inicial, a resolução virá com a sentença que contemplará tanto a decisão de mérito quanto a decisão sobre a desconsideração, assim, sendo recorrível por apelação. ${ }^{50}$ Quando no âmbito de decisão proferida por relator, será cabível agravo interno.

Conforme o estabelecido pelo artigo 137, é considerada fraude a credores a alienação ou oneração dos bens após citação.

Eventual alienação ou oneração dos bens após a citação da parte cuja personalidade se pretende

48 BARROS, André Borges de Carvalho. 0 atual panorama da desconsideração da personalidade jurídica nas relações privadas (empresariais, consumeristas e trabalhista) no direito brasileiro. Revista dos Tribunais,São Paulo, v. 107, n. 994, p. 411-435, ago. 2018, p. 426.

49 CANTALI; GUENO, op. cit., p. 83.

50 Ibid, p. 84. 
desconsiderar, nos termos do $\S 3^{\circ}$ do artigo 792 do novo código, será considerada como fraude à execução e, assim, o ato fraudulento será ineficaz perante o credor. $^{51}$

Nas justiças especializadas ainda se observa alguma relutância na correta aplicação do incidente, embora como reforça Borba "trata-se de procedimento com característica de norma geral de direito processual, sendo, portanto, aplicável a todo e qualquer processo, inclusive nos que forem regidos por leis especiais." ${ }^{52}$

Especificamente sobre a justiça do trabalho, o incidente de desconsideração da personalidade jurídica foi tratado pela Instrução Normativa no 39/2016 em seu artigo 60. ${ }^{53}$ Esta confirma que deve ser instaurado o incidente, porém ressalva que é assegurada a iniciativa do juiz do trabalho na fase de execução.

Com esta resolução, fica claro mais um desvirtuamento da desconsideração da personalidade jurídica pela justiça do trabalho, desta vez no âmbito processual, pois a própria Consolidação das Leis do Trabalho em seu artigo $769^{54}$ normatiza que o direito

51 Ibid, p. 84.

52 BORBA, op. cit., p. 42.

53 Art. $6^{\circ}$ Aplica-se ao Processo do Trabalho o incidente de desconsideração da personalidade jurídica regulado no Código de Processo Civil (arts. 133 a 137), assegurada a iniciativa também do juiz do trabalho na fase de execução (CLT, art. 878). § 1ํㅡㄹ Da decisão interlocutória que acolher ou rejeitar o incidente: TRIBUNAL SUPERIOR DO TRABALHO TRIBUNAL PLENO I - na fase de cognição, não cabe recurso de imediato, na forma do art. 893, § 1o da CLT; II - na fase de execução, cabe agravo de petição, independentemente de garantia do juízo; III - cabe agravo interno se proferida pelo Relator, em incidente instaurado originariamente no tribunal (CPC, art. 932, inciso VI). § 2 A instauração do incidente suspenderá o processo, sem prejuízo de concessão da tutela de urgência de natureza cautelar de que trata o art. 301 do CPC.

54 Art. 769 - Nos casos omissos, o direito processual comum será fonte subsidiária do direito processual do trabalho, exceto naquilo em que for incompatível com as normas deste Título. In: BRASIL. Decreto-Lei no 5.452, de 1 o de maio de 1943. Diário Oficial da União, Rio de Janeiro, 1943, paginação irregular. 
processual comum será fonte subsidiária do direito processual do trabalho, e mais específico, o artigo $855-\mathrm{A},{ }^{55}$ incluído pela reforma trabalhista, estabelece que são aplicáveis no processo do trabalho as normas previstas nos artigos 133 a 137 do Código de Processo Civil.

\section{DESCONSIDERAÇÃO DA PERSONALIDADE JURÍDICA: ANÁLISE DE CASOS CONCRETOS DOS TRIBUNAIS GAÚCHOS}

A fim de demonstrar como os tribunais vêm aplicando a teoria da desconsideração da personalidade jurídica foram realizadas pesquisas jurisprudenciais.

No Tribunal de Justiça do Estado do Rio Grande do Sul, considerado o período de um ano, de 01/10/2017 à 01/10/2018, com os parâmetros definidos como: Tipo de processo: Agravo de Instrumento; Com a expressão: desconsideração da personalidade jurídica foram encontradas 348 decisões, das quais foram efetivamente analisadas as 100 mais recentes, abrangendo o período específico de 27/09/2018 à 03/07/2018.

Para adequação com o tema proposto, das 100 decisões analisadas, foram descartadas 36 por não estarem em consonância com o tema proposto. Estas decisões tratavam de questões tributárias, consumidor, honorários advocatícios devidos pela instauração do incidente, ou recursos não analisados por problemas processuais.

Restando, portanto, 64 decisões que foram analisadas, evidenciando grande tendência a não aplicaçãoda desconsideração da personalidade jurídica, mas mesmo assim, há um grande índice de aplicação.

Das 64 decisões analisadas, em 36\% houve a aplicação da

55 Art. 855-A. Aplica-se ao processo do trabalho o incidente de desconsideração da personalidade jurídica previsto nos arts. 133 a 137 da Lei ${ }^{\circ} 13.105$, de 16 de março de 2015 - Código de Processo Civil. Ibid. 
desconsideração da personalidade jurídica, conforme demonstramos no gráfico da página a seguir.

Gráfico 1 - Análise de decisões do TJRS

TJRS - Acolheu desconsideração da personalidade jurídica?

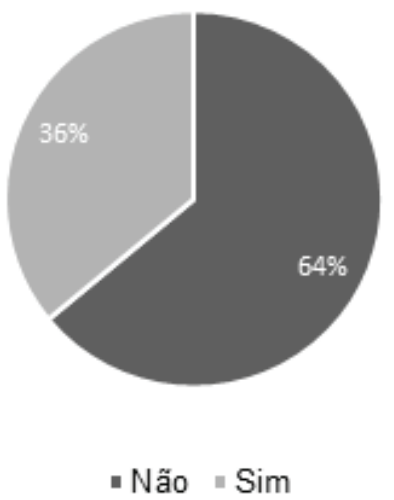

Fonte: Elaborado pela autora.

Os 36\% obtidos no resultado da pesquisa correspondem a 23 decisões, que passaremos a analisar de forma sistemática.

As hipóteses previstas no artigo 50 do Código Civil que são: desvio de finalidade e confusão patrimonial aparecem em 14 decisões como razão para aplicação da teoria da desconsideração de personalidade jurídica.

Dentre elas, interessante analisar separadamente a decisão abaixo:

Ementa: AGRAVO DE INSTRUMENTO. PROCESSUAL CIVIL. PRESCRIÇÃO INTERCORRENTE. NÃO INCIDÊNCIA. - Para reconhecimento da prescrição intercorrente, é imprescindível a comprovação da inércia do exequente, mediante a intimação pessoal do autor para diligenciar nos autos. (EDcl no ARsp 604906/MS, Min. Maria 
Isabel Gallotti, T4, Dje 02.03.2016). - Pressupostos à incidência da prescrição intercorrente não concretizada na espécie. DESCONSIDERAÇÃO DA PERSONALIDADE JURÍDICA. CABIMENTO. - A teoria da desconsideração da personalidade jurídica, medida excepcional prevista no art. 50 do Código Civil de 2002, pressupõe a ocorrência de abusos da sociedade, advindos do desvio de finalidade ou da demonstração de confusão patrimonial - AgRg no AREsp 402.622/RJ. - Caso em que o credor evidenciou os requisitos necessários, especialmente a confusão patrimonial. - Empresa executada que teve suas atividades encerradas, transferindo sua marca para exploração por outra firma, tendo os sócios da devedora fundado nova sociedade com idêntico objetivo social da devedora. Desvio de finalidade da pessoa jurídica evidenciando. Cabimento da desconsideração da personalidade jurídica na espécie. NEGARAM PROVIMENTO AO AGRAVO DE INSTRUMENTO. UNÂNIME. (Agravo de Instrumento № 70077065563, Décima Câmara Cível, Tribunal de Justiça do RS, Relator: Jorge Alberto Schreiner Pestana, Julgado em 26/07/2018). ${ }^{56}$

Aqui, se pode verificar que a abertura de nova empresa idêntica foi classificada como confusão patrimonial e desvio de finalidade. Importante decisão que atinge a principal finalidade da desconsideração da personalidade jurídica, que é evitar que fraudes sejam cometidas sob o manto da limitação de responsabilidade imposta pelas pessoas jurídicas.

Outras 6 decisões abordam o tema da dissolução irregular da sociedade para autorizar a desconsideração, para exemplificar como o referido tribunal está tratando o assunto, segue a decisão:

56 TRIBUNAL DE JUSTIÇA DO RIO GRANDE DO SUL. Décima Câmara Civil.Agravo de Instrumento: AI 70077065563 RS. Relator: Jorge Alberto Schneider Pestana. Bagé, 2018, p. 1, grifo do autor. 
Ementa: AGRAVO DE INSTRUMENTO. AÇÃO DE EXECUÇÃO. PRESCRIÇÃO INTERCORRENTE. INOCORRÊNCIA. INÉRCIA DA INSTITUIÇÃO FINANCEIRA NÃO CONFIGURADA. DESCONSIDERAÇÃO DA PERSONALIDADE JURÍDICA. POSSIBILIDADE. DA PRESCRIÇÃO INTERCORRENTE. Para reconhecimento da prescrição intercorrente,exige-se a demonstração da inércia da parte credora durante a fluência do prazo prescricional. Não evidenciado que a autora deixou de dar impulso ao processo, diligenciando em inúmeras oportunidades na busca de bens passíveis de penhora para fins de satisfação de seu crédito, não há falar em prescrição intercorrente. Precedentes. DA DESCONSIDERAÇÃo DA PERSONALIDADE JURÍDICA. Considerando as diligências infrutíferas para a localização de bens passíveis de penhora em nome da pessoa jurídica e a dissolução irregular da empresa, cabível a desconsideração da personalidade jurídica, nos termos do art. 50 do Código Civil e da Súmula 435 do STJ. Mantida a inclusão dos sócios da empresa executada no polo passivo da demanda. AGRAVO DE INSTRUMENTO DESPROVIDO. (Agravo de Instrumento № 70078496809, Décima Terceira Câmara Cível, Tribunal de Justiça do RS, Relator: André Luiz PlanellaVillarinho, Julgado em 30/08/2018). ${ }^{57}$

Para acolher esta tese, deverá estar provado no processo de forma robusta que a empresa cuja personalidade jurídica deverá ser desconsiderada, embora se mantenha ativa perante os cadastros da Receita Federal do Brasil e da Junta Comercial, não possui mais atividade, ou seja, que simplesmente "fechou as portas." Neste sentido, foi editada a Súmula 435 do Superior Tribunal de Justiça a qual estabelece que "presume-se dissolvida

57 TRIBUNAL DE JUSTIÇA DO RIO GRANDE DO SUL. Décima Sétima Câmara Cível. Agravo de Instrumento № 70078708641. Relator: Gelson Rolim Stocker. Porto Alegre, 2018, p. 1, grifo do autor. 
irregularmente a empresa que deixar de funcionar no seu domicílio fiscal, sem comunicação aos órgãos competentes, legitimando o redirecionamento da execução fiscal para o sócio-gerente." 58

Nota-se que a aplicação da desconsideração da personalidade jurídica nestes casos tem se tornado comuns, evidenciando que a atividade empresarial está optando por simplesmente encerrar suas atividades na prática e nãoobedecendo o correto formato previsto na legislação. Entende-se que cabe estudo sobre o porquê deste fenômeno, destacamos como mais evidente a grave crise econômica e as elevadas taxas e burocracias envolvidas em um processo de baixa de uma pessoa jurídica.

As outras 3 decisões, versam sobre a aplicação do incidente previsto no Código de Processo Civil.

Ementa:AGRAVO DE INSTRUMENTO. DECISÃO MONOCRÁTICA. AÇÃO DE EXECUÇÃO DE TÍTULO EXTRAJUDICIAL. INSTAURAÇÃO DO INCIDENTE DE DESCONSIDERAÇÃOO DA PERSONALIDADE JURÍDICA. - Presentes indícios do preenchimento dos requisitos do art. 50 do $\mathrm{CC}$, bem como dos arts. 133 e 134 do CPC, possível a instauração do incidente de desconsideração da personalidade jurídica da sociedade empresária. - No caso dos autos, há duas pessoas jurídicas constituídas no mesmo endereço, com as mesmas atividades, no entanto, com CNPJs e razões sociais diversas. Ademais, embora nenhum ativo seja localizado em nome da devedora, as páginas em redes sociais demonstram plena atividade, motivo para o deferimento do processamento do incidente. AGRAVO PROVIDO. (Agravo de Instrumento № 70078708641, Décima Sétima Câmara Cível, Tribunal de Justiça do RS, Relator: Gelson Rolim Stocker, Julgado em 23/09/2018). ${ }^{59}$

58 SUPERIOR TRIBUNAL DE JUSTIÇA. Súmula 435. Primeira seção, julgado em 14/04/2010. Diário da Justiça Eletrônico, Brasília, 2010, paginação irregular.

59 TRIBUNAL DE JUSTIÇA DO RIO GRANDE DO SUL, op. cit., 2018, p. 1, grifo do autor. 
Em consonância com o já explanado no capítulo específico sobre o supracitado incidente, provados os indícios de aplicação das hipóteses do artigo 50 do Código Civil, é aplicável a abertura do incidente para apuração se a desconsideração é cabível ou não.

Passando para a análise das 41 decisões que negaram a desconsideração da personalidade jurídica, destacamos o elevado número de 15 onde os motivos principais são a não instauração do incidente ou a não concessão de contraditório.

Ementa:AGRAVO DE INSTRUMENTO. DIREITO PRIVADO NÃO ESPECIFICADO. INCIDENTE DE DESCONSIDERAÇÃO DA PERSONALIDADE JURÍDICA. AUSÊNCIA DE INTIMAÇÃO DOS SÓCIOS. VIOLAÇÃO À AMPLA DEFESA E AO CONTRADITÓRIO. Instaurado incidente de desconsideração da personalidade jurídica que visa à responsabilização dos sócios pela dívida da empresa, deve, nos termos do artigo 135 do CPC/2015, ser realizada a citação dos sócios, oportunizando lhes o exercício da ampla defesa e do contraditório. Caso concreto em que se revela impositiva a desconstituição da decisão agravada, em virtude da inobservância do procedimento legal. Decisão agravada desconstituída, de ofício. (Agravo de Instrumento № 70077690378, Décima Segunda Câmara Cível, Tribunal de Justiça do RS, Relator: Umberto GuaspariSudbrack, Julgado em $26 / 07 / 2018) .{ }^{60}$

A decisão acima demonstra questão de grave violação do direito ao contraditório dos sócios da empresa demandada, além do elevado número de descuidos com o devido processo legal que os juízes de $1^{a}$ grau estão tendo em relação a instauração do incidente e seu correto procedimento, fazendo com que estas questões cheguem até o Tribunal de Justiça sem necessidade.

60 TRIBUNAL DE JUSTIÇA DO RIO GRANDE DO SUL. Décima Segunda Câmara Cível. Agravo de Instrumento № 70077690378. Relator: Umberto GuaspariSudbrack. Porto Alegre, 2018, p. 1, grifo do autor. 
Uma das decisões diz respeito ao disposto no parágrafo $4^{\circ}$ do artigo 134 do Código de Processo Civil, que estabelece que o requerimento de abertura do incidente de desconsideração da personalidade jurídica deve demonstrar os pressupostos legais específicos para tal.

Ementa: AGRAVO DE INSTRUMENTO. DIREITO PRIVADO NÃO ESPECIFICADO. AÇÃO DECLARATÓRIA DE NULIDADE DE DUPLICATA MERCANTIL C/C SUSTAÇÃO DE PROTESTO E INDENIZATÓRIA. INCIDENTE DE DESCONSIDERAÇÃO DA PERSONALIDADE JURÍDICA. EMENDA À INICIAL DO INCIDENTE. MANUTENÇÃO DA DECISÃO AGRAVADA. Nos termos do art. 133 e 137, do Código de Processo Civil, a desconsideração da personalidade jurídica é medida excepcional que somente pode ser instaurada quando caracterizado o desvio de finalidade ou a confusão patrimonial, sendo necessária a abertura de incidente para tal. Outrossim, o art. 134, §4은 do mesmo diploma processual dispõe que o incidente, para fins de admissibilidade, deve ser instruído com prova suficiente a embasar a fundamentação da parte autora, motivo pelo qual é de se manter a decisão agravada que intimou o agravante a emendar a sua inicial, ante a ausência dos referidos pressupostos. NEGARAM PROVIMENTO AO AGRAVO DE INSTRUMENTO. UNÂNIME. (Agravo de Instrumento № 70077487510 , Vigésima Câmara Cível, Tribunal de Justiça do RS, Relator: Glênio José WassersteinHekman, Julgado em 08/08/2018). ${ }^{61}$

Assim, consolidando entendimento de que o requerimento deve ser instruído com provas que levantem robusta probabilidade de ocorrência das hipóteses legais previstas no Código Civil.

${ }_{61}$ TRIBUNAL DE JUSTIÇA DO RIO GRANDE DO SUL. Vigésima Câmara Cível. Agravo de Instrumento № 70077487510. Relator: Glênio José WassersteinHekman. Porto Alegre, 2018, p. 1, grifo do autor. 
Dentre as 24 decisões restantes, todas estão fundamentadas conforme o artigo 50 do Código Civil, importante exibir o exemplo abaixo, para evidenciar a interpretação do referido artigo e da teoria estudada por este artigo.

Ementa: AGRAVO DE INSTRUMENTO. DIREITO PRIVADO NÃO ESPECIFICADO. AÇÃO DE EXECUÇÃO DE TÍTULO EXTRAJUDICIAL. DESCONSIDERAÇÃO DA PERSONALIDADE JURÍDICA. DESCABIMENTO. REQUISITOS NÃO COMPROVADOS. O Código Civil Brasileiro, em seu art. 50, adotou a chamada Teoria Maior da Desconsideração, exigindo, para que se possa desconsiderar a personalidade jurídica, não só a insolvência da pessoa jurídica, como, também, a prova de requisitos legais específicos. Dessa forma, temse que a insuficiência patrimonial, a insolvência ou inadimplência não se apresentam, de per si, como causas suficientes para que se possa desconsiderar a personalidade jurídica. $\mathrm{Ne}$ cessário, ainda, que se comprove que esse estado econômico tenha decorrido de desvio de finalidade (desrespeito ao objetivo social da empresa), confusão patrimonial ou dissolução irregular da pessoa jurídica, requisitos específicos esses não demonstrados na hipótese. NEGARAM PROVIMENTO. UNÂNIME. (Agravo de Instrumento № 70077923209, Décima Oitava Câmara Cível, Tribunal de Justiça do RS, Relator: Pedro Celso Dal Pra, Julgado em 27/09/2018). ${ }^{62}$

Após as devidas análises, fica demonstrado que o Tribunal de Justiça do Estado do Rio Grande do Sul, tem se atentado para a aplicação da desconsideração da personalidade jurídica baseando-se somente no artigo 50 do Código Civil não utilizando

62 TRIBUNAL DE JUSTIÇA DO RIO GRANDE DO SUL. Décima Oitava Câmara Cível. Agravo de Instrumento № 70077923209. Relator: Pedro Celso Dal Pra. Porto Alegre, 2018, p. 1, grifo do autor. 
outras teorias, porém ainda chama a atenção que mesmo assim, o número de casos em que há a aplicação desta é elevado.

Na análise das decisões no Tribunal Regional do Trabalho da 4⿳亠丷a Região, foi aplicado o mesmo período, com os parâmetros definidos como: Trecho exato: Desconsideração da personalidade jurídica; Classe: Agravo de petição. Foram encontradas 855 decisões, dos quais foram analisadas 20 aleatórias durante o período selecionado automaticamente pelo site de pesquisa do referido tribunal, dentre estas somente duas foram classificadas como fora do tema: uma por se tratar de discussão sobre contribuição sindical e outra por se tratar sobre categoria com lei própria que regulamenta os casos de desconsideração da personalidade jurídica.

Cabe ressaltar que o número de decisões analisadas foi menor em comparação com o Tribunal de Justiça do Estado do Rio Grande do Sul, pois os resultados foram todos positivos para a aplicação da desconsideração, tornando assim a pesquisa satisfatória com este montante de decisões.

Como já apontado nos tópicos anteriores, a Justiça do Trabalho utiliza seus próprios critérios para a aplicação da personalidade jurídica, baseados somente em construções desta mesma, onde o simples inadimplemento da pessoa jurídica já é motivo para a desconsideração.

Dentre as 18 decisões analisadas, 5 delas citaram o Código de Defesa do Consumidor, como exemplo abaixo:

AGRAVO DE PETIÇÃO. DESCONSIDERAÇÃO DA PERSONALIDADE JURÍDICA. REDIRECIONAMENTO DOS SÓCIOS. Quando a empresa executada é insolvente e demonstrada a impossibilidade de se continuar a execução, aplica-se a teoria menor da desconsideração da personalidade jurídica. (TRT da 4a Região, Seção Especializada em Execução, 0000477-65.2013.5.04.0831 AP, em 20/06/2018, Juiz Convocado Roberto Antonio Carvalho Zonta). ${ }^{63}$

63 TRIBUNAL REGIONAL DO TRABALHO DA 4⿳a REGIÃO. Seção Especializada em Execução. 0000477-65.2013.5.04.0831 AP. Juiz Convocado Roberto Antonio Carvalho Zonta. Porto Alegre, 2018, p. 1. 
Por se tratar de ementa muito resumida, cito também trecho da referida decisão:

É preciso destacar que, de acordo com a Teoria Menor da Desconsideração da Personalidade Jurídica adotada na esfera dos pretórios trabalhistas, basta a prova da insolvência da sociedade para que seja declarada a desconsideração da personalidade da empresa, com o direcionamento da execução sobre os bens dos sócios, sem que haja necessidade de restar demonstrada confusão patrimonial, fraude, ato ilícito praticado pelos sócios administradores etc.

Nesse sentido, são os precedentes desta Seção Especializada que ora colaciono:

AGRAVO DE PETIÇÃO. DESCONSIDERAÇÃO DA PERSONALIDADE JURÍDICA. Conforme a teoria objetiva da desconsideração da personalidade jurídica, prevista no artigo 28 do CDC e artigo $4^{\circ}$ da Lei $n^{\circ}$ 9.605/1998, basta o credor demonstrar a insolvência da parte contrária que será possível retirar o véu da pessoa jurídica, com o consequente ataque ao patrimônio dos sócios. Tal teoria objetiva, em razão da hipossuficiência do trabalhador, da natureza alimentícia dos créditos trabalhistas e de todo o sistema principiológico protecionista que foi edificado para proteger o trabalhador, é a que melhor atende aos primados do Direito do Trabalho, devendo ser utilizada enquanto não houver previsão específica nos diplomas trabalhistas. (TRT da $4^{a}$ Região, Seção Especializada em Execução, 008020058.2006.5.04.0030 AP, em 23/02/2018, Desembargador Joao Alfredo Borges Antunes de Miranda). ${ }^{64}$

Todas as demais decisões são baseadas em argumentos próprios da Justiça do Trabalho, e o surpreendente é que o Tribunal

64 TRIBUNAL REGIONAL DO TRABALHO DA 4⿳亠丷a REGIÃO, op. cit., p. 1, grifo do autor. 
Regional do Trabalho da 4⿳a Região tem entendido que não é necessária a instauração do incidente nos processos trabalhistas, e trata a já referida Instrução Normativa 39/2016 em seu artigo 6ํㅜㄴ, como simples recomendação. Como exemplo:

AGRAVO DE PETIÇÃO DA EXEQUENTE. REDIRECIONAMENTO DA EXECUÇÃO. INCIDENTE DE DESCONSIDERAÇÃO DA PERSONALIDADE JURÍDICA. DESNECESSIDADE. A desconsideração da personalidade jurídica e o consequente redirecionamento da execução contra os sócios prescindem da instauração do incidente de desconsideração previsto no Código de Processo Civil. Entendimento pacificado no âmbito da Seção Especializada em Execução. (TRT da 4⿳a Região, Seção Especializada em Execução, 0056100-57.1997.5.04.0029 AP, em 06/06/2018, Desembargadora Maria da Graça Ribeiro Centeno). ${ }^{66}$

Para melhor elucidar a questão, seguem trecho da decisão:

Embora não se desconheça a previsão do artigo 6o da Instrução Normativa no 39/2016 do Tribunal Superior do Trabalho, a qual considera

65 Art. $6^{\circ}$ Aplica-se ao Processo do Trabalho o incidente de desconsideração da personalidade jurídica regulado no Código de Processo Civil (arts. 133 a 137), assegurada a iniciativa também do juiz do trabalho na fase de execução (CLT, art. 878). § 1ํㅡㄹ decisão interlocutória que acolher ou rejeitar o incidente: TRIBUNAL SUPERIOR DO TRABALHO TRIBUNAL PLENO I - na fase de cognição, não cabe recurso de imediato, na forma do art. 893, § 1을 da CLT; II - na fase de execução, cabe agravo de petição, independentemente de garantia do juízo; III - cabe agravo interno se proferida pelo Relator, em incidente instaurado originariamente no tribunal (CPC, art. 932, inciso VI). $§ 2^{\circ}$ A instauração do incidente suspenderá o processo, sem prejuízo de concessão da tutela de urgência de natureza cautelar de que trata o art. 301 do CPC. In: TRIBUNAL SUPEROR DO TRABALHO. Resolução no 203, de 15 de março de 2016. Brasília, 2016, p. 4.

66 TRIBUNAL REGIONAL DO TRABALHO DA 4⿳⺈ REGIÃO. Seção Especializada em Execução. 0056100-57.1997.5.04.0029 AP. Desembargadora Maria da Graça Ribeiro Centeno. Porto Alegre, 2018, p. 1. 
aplicável o referido incidente ao processo do trabalho, entendo, na linha do entendimento desta Seção Especializada em Execução, e diante da ausência de efeito impositivo e vinculante da mencionada norma, que a desconsideração da personalidade jurídica e o consequente redirecionamento da execução contra os sócios independem da instauração do incidente de desconsideração previsto no Código de Processo Civil. ${ }^{67}$

Aqui fica evidenciada a falta de segurança jurídica existente na Justiça do Trabalho quando se trata da desconsideração da personalidade jurídica, uma vez que o Tribunal da 4⿳a Região não cumpre nem mesmo as recomendações do Tribunal Superior do Trabalho, pelo simples motivo de não as considerarem impositivas e vinculantes.

Verifica-se urgente a necessidade de regulamentação efetiva quanto a desconsideração da personalidade jurídica nas justiças especializadas. Como o empresário brasileiro poderá ter segurança dos riscos que corre ao empreender se cada justiça entende a matéria de uma forma diferente? E ainda como evidenciado na Justiça do Trabalho, nem mesmo entre tribunais superiores e regionais existe uma uniformidade de entendimentos?

\section{CONSIDERAÇÕES FINAIS}

0 instituto da desconsideração da personalidade jurídica deve ser analisado muito cuidadosamente pelos aplicadores do direito, uma vez que não interfere somente nas matérias específicas do direito, mas também, e principalmente na economia. Com o avanço dos conhecimentos e tecnologias cada vez mais se faz necessário que as decisões sejam tomadas em consonância com o cenário global como um todo, não se pode mais tratar

67 TRIBUNAL REGIONAL DO TRABALHO DA 4⿳亠丷a REGIÃO. Seção Especializada em Execução. 0056100-57.1997.5.04.0029 AP. Desembargadora Maria da Graça Ribeiro Centeno. Porto Alegre, 2018, p. 1. 
questões jurídicas como se elas tivessem efeitos somente em casos pontuais.

A constituição de uma pessoa jurídica com um dos tipos societários de responsabilidade limitada é um grande incentivador e aquecedor da economia, evidentemente porque protege o patrimônio pessoal dos sócios.

Isto faz com que os empresários aceitem correr mais riscos para gerar riquezas, não apenas para si próprios, mas também para a sociedade e para o Estado. Tanto que, como já referido anteriormente em levantamento realizado pela própria Junta Comercial, Industrial e Serviços do Estado do Rio Grande do Sul, estes são os tipos societários mais utilizados atualmente.

Justamente por se tratar de um benefício concedido aos empresários, a proteção de uma pessoa jurídica com responsabilidade limitada dada pela constituição não está imune a deturpações feitas por pessoas com más intenções, que visam o cometimento de fraudes e desvios sob a sua proteção. Para isto, temos a desconsideração da personalidade jurídica, construção do direito que visa a "punição" destes empresários com más intenções.

Por se tratar de uma "punição", o instituto da desconsideração da personalidade jurídica deve ser tratado como exceção e jamais como regra. Em nosso ordenamento jurídico, a efetiva regulação deste instituto está no Código Civil em seu artigo 50, que estabelece condições claras para sua aplicação.

A aplicação deste instituto indiscriminadamente pode ser geradora de forte impacto econômico e social, trazendo insegurança jurídica. Por este motivo é necessário que sua aplicação seja efetuada com cuidado.

Inicialmente o que se conclui com a pesquisa teórica, é que embora a regra matriz da desconsideração da personalidade jurídica esteja no Código Civil, existem tantas outras legislações específicas, que regulam a mesma matéria de forma diversa.

Assim a graduação do risco de desconsideração da personalidade jurídica depende da matéria a ser discutida. Considerando 
estas premissas, o empresário nunca tem certeza se o risco é grande ou pequeno.

Vê-se um crescente entendimento de alguns ramos do direito de que a personalidade jurídica é apenas um obstáculo para a solução dos problemas, sob o motivo de que as outras partes processuais são sempre hipossuficientes e de que os empresários não merecem nenhum tipo de proteção contra os riscos assumidos quando da decisão de empreender.Aqui citamos principalmente o direito do consumidor e o direito trabalhista.

0 estudo da jurisprudência com delimitação específica para a área cível e trabalhista, possibilitou a conclusão de que a área cível tem tido maior cuidado e rigor em suas decisões, sempre se pautando pelas regras do artigo 50 do Código Civil, embora ainda chame a atenção o número de casos em que a desconsideração é aplicada. Não se pode concluir com certeza o que causa este fenômeno, uma vez que o Brasil passa por grande crise econômica, o que pode levar cada vez mais empresários a cometerem irregularidades como tentativa de manter sua atividade empresarial. Cabe ressaltar o grande número de decisões baseadas na dissolução irregular da empresa, casos em que estas simplesmente "fecham suas portas" e param de funcionar.

Já na área trabalhista o que se identificou foi a desconsideração da personalidade jurídica em 100\% das decisões analisadas, ainda com o agravante de que o Tribunal Regional do Trabalho da 4⿳亠丷a Região não considera necessária a instauração do incidente de desconsideração da personalidade jurídica, indo contra Instrução Normativa do próprio Tribunal Superior do Trabalho, a Consolidação das Leis do Trabalho e o Código de Processo Civil.

Não se discute neste artigo os méritos dos motivos elencados pela Justiça do Trabalho, principalmente o caráter alimentar dos créditos em discussão em seus processos, porém nos parece um tanto arbitrárias as decisões baseadas somente em construções jurisprudenciais, que ainda ao analisar a Instrução Normativa 
39/2016 e a Consolidação das Leis do Trabalho, vão contra entendimentos legislativos e do Tribunal Superior do Trabalho.

O que se identifica com esta análise é uma grande insegurança jurídica quando se trata do instituto da desconsideração da personalidade jurídica, principalmente em justiças especializadas, como a Justiça do Trabalho. Não se encontra uma regra geral, pois os casos estão sujeitos a interpretação de diversas legislações específicas e entendimentos jurisprudenciais que divergem até mesmo entre si.

Por fim, importante buscar um elemento pacificador quanto a matéria, criando regras mais claras e objetivas, seguindo o exemplo das decisões de matérias cíveis, onde realmente se identifica uma crescente segurança jurídica com as decisões analisadas neste artigo.

\section{REFERÊNCIAS}

BARROS, André Borges de Carvalho. 0 atual panorama da desconsideração da personalidade jurídica nas relações privadas (empresariais, consumeristas e trabalhista) no direito brasileiro. Revista dos Tribunais,São Paulo, v. 107, n. 994, p. 411-435, ago. 2018.

BORBA, José Edwaldo Tavares. Direito societário. 16. ed. São Paulo: Atlas, 2018.

BRASIL. Decreto-Lei $n^{\circ} 5.452$, de $1^{\circ}$ de maio de 1943. Diário Oficial da União, Rio de Janeiro, 1943.

BRASIL. Lei no 10.406, de 10 de janeiro de 2002.Diário Oficial da União, Brasília, 2002.

BRASIL. Lei no 12.529, de 30 de novembro de 2011.Diário Oficial da União, Brasília, 2011.

BRASIL. Lei no 13.105, de 16 de março de 2015. Diário Oficial da União, Brasília, 2015.

BRASIL. Lei no 6.404, de 15 de dezembro de 1976.Diário Oficial da União, Brasília, 1976.

BRASIL. Lei no 8.078, de 11 de setembro de 1990. Diário Oficial da União, Brasília, 1990. 
BRASIL. Lei no 9.606, de 16 de fevereiro de 1998. Diário Oficial da União, Brasília, 1988.

CAMARGO, André Antunes Soares de. A pessoa jurídica: um fenômeno social antigo, recorrente, multidisciplinar e global. In: FRANÇA, Erasmo. (Org.). Direito societário contemporâneo.São Paulo: QuartierLatin, 2009.

CANTALI, Fernanda Borghetti; GUENO, Aline Woltz. A Desconsideração da Personalidade Jurídica para a Responsabilização Patrimonial de Ex-Sócio. Justiça \& Sociedade, Porto Alegre, v. 1, n. 1, p. 117-146, 2016.

CANTALI, Fernanda Borghetti; GUENO, Aline Woltz. Dos sujeitos do processo.In: MELLO, Rafael Corte (Org.), GIORGI JR., Romulo Ponticelli (Org.). Novo código de processo civil anotado. Charleston: CreateSpaceIndependentPublishing Platform, 2015.

CATEB, Alexandre Bueno; PIMENTA, Eduardo Goulart. Análise econômica do direito societário. In: TIMM, Luciano. (Org.). Direito e economia no Brasil. 2. ed. São Paulo: Atlas, 2014.

COELHO, Fábio Ulhoa. Desconsideração da Personalidade Jurídica. São Paulo: Editora Revista dos Tribunais, 1989.

COELHO, Fábio Ulhoa. Manual de direito comercial: direito de empresa. 23. ed. São Paulo: Saraiva, 2011.

FORGIONI, Paula Andrea. A evolução do direito comercial brasileiro: da mercancia ao mercado. 3. ed. São Paulo: Editora Revista dos Tribunais, 2016

LORENZETTI, Ari Pedro. A Responsabilidade dos Sócios e Dirigentes no Processo do Trabalho e o Incidente de Desconsideração. In. CLAUS,Ben-hur Silveira; ALVARENGA,Rúbia Zanotellide.(Orgs.).Execução Trabalhista: o desafio da efetividade. São Paulo: LTr, 2015.

NEVES, Daniel Amorim Assumpção. Novo Código de Processo Civil: leis 13.105/2015 e 13.256/2016. 3. ed. São Paulo: Método, 2016.

OLIVEIRA, Francisco Antonio de. Comentários à Execução do Novo Código de Processo Civil: enfoques civilistas e trabalhistas. São Paulo: LTr, 2016.

PAZIM, Ronaldo Zanata. A desconsideração da personalidade jurídica como um golpe letal ao direito empresarial. Revista Síntese, Direito Empresarial,São Paulo, v. 9, n. 51, Jul/Ago. 2016. 
RAMOS, André Luiz Santa Cruz. Direito empresarial. 7. ed. São Paulo: Método, 2017.

RIO GRANDE DO SUL. Junta Comercial, Industrial e Serviços do Rio Grande do Sul. Relação por Ano das Estatísticas. Porto Alegre, 2017. Disponível em: <https://jucisrs.rs.gov.br/estatisticas>. Acesso em: 11 nov. 2018.

SCHIAVI, Mauro. Manual de direito processual do trabalho. 7. ed. São Paulo: LTr, 2014.

SILVA, Leonardo Toledo da. Abuso da desconsideração da personalidade jurídica. São Paulo: Saraiva, 2014.

SUPERIOR TRIBUNAL DE JUSTIÇA. Súmula 435. Primeira seção, julgado em 14/04/2010. Diário da Justiça Eletrônico, Brasília, 2010.

TOMAZETTE, Marlon. Curso de direito empresarial: teoria geral e direito societário. 6. ed. São Paulo: Atlas, 2014. V. 1.

TRIBUNAL DE JUSTIÇA DO RIO GRANDE DO SUL. Décima Câmara Civil. Agravo de Instrumento: AI 70077065563 RS. Relator: Jorge Alberto Schneider Pestana. Bagé, 2018.

TRIBUNAL DE JUSTIÇA DO PARANÁ. 4ạ Turma. Resp 1.729.554/SP. Relator: Ministro Luis Felipe Salomão, julgado em 08/05/2018. Diário da Justiça Eletrônico, Curitiba, 2018.

TRIBUNAL DE JUSTIÇA DO RIO GRANDE DO SUL.Décima Oitava Câmara Cível. Agravo de Instrumento № 70077923209. Relator: Pedro Celso Dal Pra. Porto Alegre, 2018.

TRIBUNAL DE JUSTIÇA DO RIO GRANDE DO SUL. Décima Segunda Câmara Cível.Agravo de Instrumento № 70077690378.Relator: Umberto GuaspariSudbrack. Porto Alegre, 2018.

TRIBUNAL DE JUSTIÇA DO RIO GRANDE DO SUL. Décima Sétima Câmara Cível. Agravo de Instrumento № 70078708641. Relator: Gelson Rolim Stocker. Porto Alegre, 2018.

TRIBUNAL DE JUSTIÇA DO RIO GRANDE DO SUL. Vigésima Câmara Cível. Agravo de Instrumento № 70077487510. Relator: Glênio José WassersteinHekman. Porto Alegre, 2018.

TRIBUNAL REGIONAL DO TRABALHO DA 4⿳亠丷a REGIÃO. Seção Especializada em Execução. 0000477-65.2013.5.04.0831 AP. Juiz Convocado Roberto Antonio Carvalho Zonta. Porto Alegre, 2018. 
TRIBUNAL REGIONAL DO TRABALHO DA 4⿳亠丷厂 REGIÃO. Seção Especializada em Execução. 0056100-57.1997.5.04.0029 AP. Desembargadora Maria da Graça Ribeiro Centeno. Porto Alegre, 2018.

TRIBUNAL RERGIONAL DO TRABALHO DA 4⿳亠丷a REGIÃO.Seção Especializada em Execução.0020067-11.2014.5.04.0405 AP. Desembargador Joao Alfredo Borges Antunes de Miranda. Caxias do Sul, 2018.

TRIBUNAL SUPEROR DO TRABALHO. Resolução no 203, de 15 de março de 2016. Brasília, 2016. 